\title{
ROBO3 Gene
}

National Cancer Institute

\section{Source}

National Cancer Institute. ROBO3 Gene. NCI Thesaurus. Code C126777.

This gene is involved in neuronal cell shape. 